\title{
Differentiation of apomictic and sexual genotypes of Brachiaria spp., using molecular markers
}

\section{Diferenciación de genotipos apomícticos y sexuales de Brachiaria spp., con marcadores moleculares}

\author{
Jaime Poblete-Vargas ${ }^{1}$, Ernestina Valadez-Moctezuma ${ }^{2 *}$, Gabino García de los Santos ${ }^{1}$, Carlos \\ Martínez-Flores ${ }^{3}$, Armando Peralta-Martínez ${ }^{4}$ \\ ${ }^{1}$ Programa de Semillas, Colegio de Postgraduados Campus Montecillo. Km 36.5 Carretera México- Texcoco, CP. 56230, \\ Montecillo, Texcoco, Estado de México, México. \\ ${ }^{2}$ Laboratorio de Biología Molecular, Departamento de Fitotecnia. Universidad Autónoma Chapingo. Carretera México-Texcoco \\ Km 38.5 Chapingo, CP. 56230, Estado de México, México. \\ ${ }^{3}$ Programa Global de Maíz. Centro Internacional de Mejoramiento de Maíz y Trigo. Carretera México-Veracruz. Km. 45, \\ Colonia El Batán, CP. 56237, Texcoco, Estado de México, México. . \\ ${ }^{4}$ Agroproductos de Iguala, S.A. de C.V. Hidalgo No. 23, Col. Centro, CP. 40400, Iguala, Guerrero, México. \\ ${ }^{*}$ Corresponding author: evaladez@chapingo.mx
}

Scientific note received: August 03,2016 accepted: May 11, 2017

\begin{abstract}
Some species of Brachiaria are cultivated in the tropics because of their high productivity and drought resistance; their apomictic hybrids are of interest because of the almost null segregation and fixation of the hybrid vigor in seeds. In this research, Amplified Fragment Length Polymorphism (AFLP) and Cleaved Amplified Polymorphic Sequence (CAPS) markers were used to differentiate apomictic tetraploid and sexual diploid Brachiaria parents and their progeny. Polymorphism detected with AFLP was $91.3 \%$ and with CAPS $79.7 \%$. Phenograms differentiated each genotype and the clustering of parents and their progeny was by their degree of genetic relatedness. AFLP did not separate the apomictic genotypes from the sexual ones, but CAPS markers did so through the C15-8 marker. Some apomictic genotypes of the progeny inherited it from their $B$. ruziziensis sexual mother, which may be related to some segregating character of the parental line.
\end{abstract}

Key words: AFLP; CAPS; DNA; forage; polymorphism.

RESUMEN. Algunas especies de Brachiaria se cultivan en los trópicos por su alta productividad y resistencia a sequía; sus híbridos apomicticos, son de interés por la casi nula segregación y fijación del vigor híbrido. En este trabajo se utilizaron marcadores Amplified Fragment Length Polymorphism (AFLPs) y Cleaved Amplified Polymorphic Sequences (CAPS) para diferenciar progenitores apomícticos tetraploides y sexuales diploides de Brachiaria y su progenie. El polimorfismo detectado con AFLPs fue del $91.3 \%$ y con CAPS del 79.7\%. Los fenogramas diferenciaron a cada genotipo y agrupación de progenitores con la progenie por su grado de parentesco genético. Los AFLPs no separaron a los genotipos apomícticos de los sexuales, pero los CAPS si lo lograron mediante el marcador C15-8; algunos genotipos apomícticos de la progenie, lo heredaron de la madre sexual B. ruziziensis, lo que puede estar relacionado con algún carácter segregante de la línea progenitora.

Palabras clave:

\section{INTRODUCTION}

Livestock production is a key sector in the economies of Latin American countries, occupying a large area of land with productive potential (FAO 2009). Among the forage plants used, the genus Brachiaria, which is characterized by having cultivated forage pastures, stands out (Do Valle and 


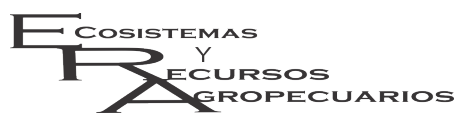

Poblete-Vargas et al. Molecular differentiation of Brachiaria sp.

Ecosist. Recur. Agropec. 5(13):71-80,2018

Miles et al. 2001). The success of these pastures is due to the fact that many species have a wide natural variation in agronomic traits, such as biomass production, nutrient quality, drought tolerance, tolerance to flooded soils and high seed yields (Miles et al. 2004). The qualities of these forage species have been the reason for developing hybrids with resistance to cuckoo spit, the frothed-up sap caused by the spittlebug (Aeneolamia postica), which limits the passage of water and nutrients in the plant (De la Cruz-Llanas et al. 2005), and to foliar fungi such as Rhizotocnia; hybrids have also been developed that are adapted to acid soils with high levels of aluminum (Rao et al. 2006) and that have higher production of high digestibility forage (Lascano 2002). Most commercially cultivated Brachiaria species are tetraploid apomicts; only B. ruzizienzis reproduces sexually and its recombination with apomictic genotypes can generate hybrids with desirable characteristics (Miles et al. 2004).

Apomixis is present in some Brachiaria species, which implies that the progeny are genetically identical to the mother plant, so they do not present segregation, a phenomenon that is often of importance in plant breeding (Grimanelli et al. 2001). This character is considered relevant in agriculture, due to the possibility of transforming crops of worldwide importance from sexual reproduction to apomictic clones (Bicknell and Koltunow 2004). Apomixis has great agricultural interest, as its fixation would allow maintaining the genetic stability of hybrids and varieties for an indefinite period, while the progeny of sexual reproduction maintain their genetic variation (Koltunow et al. 1995). B. decumbens, $B$. brizantha and $B$. ruziziensis are considered the most important species in this regard, since they belong to the same agomictic complex, with the first two being apomictic and the last one sexual (Do Valle and Miles 2001, Risso-Pascotto et al. 2005).

Traditionally in Brachiaria, morphological descriptors and embryo sac analysis with pistil thinning techniques are used to differentiate progeny and determine whether $F_{1}$ individuals are apomictic or sexual (Savidan 2000), while genetic-molecular marker techniques have been used successfully since the 1990s, with the advantage that they provide results in a short time from any plant tissue and any plant age; they are efficient because they are not affected by the environment. In most cases, the markers complement the information from the morphological markers (Azofeifa-Delgado 2006). In particular, the Amplified Fragment Length Polymorphism (AFLP) and Cleaved Amplified Polymorphic Sequence (CAPS) techniques are used to sample the entire genome (Zorzatto et al. 2010). Therefore, the objective of the present study was to apply the AFLP and CAPS techniques to differentiate interspecific and sexual apomictic genotypes of Brachiaria spp, selected as apomictic in the field.

\section{MATERIALS AND METHODS}

\section{Plant material}

We used young seedling leaves from 30 hybrid genotypes from three artificial hybrid tetraploid $(2 n$ $+2 n=4 n=36)$ male $\left(\sigma^{7}\right)$ apomictic Brachiaria brizantha $\times B$. ruziziensis parents; five tetraploid female (o) Braploiaria ruziziensis $(4 \mathrm{x}=36)$ parents and 22 hybrids of the progeny resulting from 10 crosses selected in the field with the apomixis character (Table 1). The parent $0^{x} 18$ (BR/NO 1873 ) is registered in Mexico as cultivar Mulato I, characterized by having high genetic uniformity; parent $\sigma^{7} 71$ (BR/NO 1371) is facultative, only produces viable pollen and is identified as selfcompatible (CIAT 2002); it was used as a pollinator because it is a cuckoo spit-resistant apomict. Parent $0^{7} 94$ (AIG 2094) is a seed-producing, droughtresistant hybrid. The progeny tests for identifying the reproductive mode of the mother plants and the 22 apomictic hybrids were carried out in an experimental lot in Tuxpan, Iguala county, Guerrero state, Mexico, located at $18^{\circ} 21^{\prime} \mathrm{NL}, 99^{\circ} 29^{\prime} \mathrm{WL}$.

\section{DNA extraction}

From $1 \mathrm{~g}$ of lyophilized tissue obtained from the mixture of the genotypes listed in Table 1 , the DNA was obtained with the cetyltrimethylammo- 
Poblete-Vargas et al.

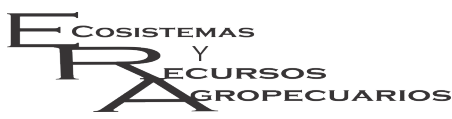

Molecular differentiation of Brachiaria sp.

Ecosist. Recur. Agropec.

5(13):71-80,2018

Table 1. Genetic material and keys used in molecular characterization.

\begin{tabular}{|c|c|c|c|c|}
\hline No. & Genotype & & Key* & Origen** \\
\hline 1 & Parent $\sigma^{x} 4 \mathrm{X}$ & Apomictic & 71 & Brachiaria brizantha $\times$ B. ruziziensis \\
\hline 2 & Parent $\sigma^{\pi} 4 \mathrm{X}$ & Apomictic & 94 & Brachiaria brizantha $\times B$. ruziziensis \\
\hline 3 & Parent $\sigma^{7} 4 \mathrm{X}$ & Apomictic & 18 & Brachiaria brizantha $\times$ B. ruziziensis \\
\hline 4 & Parent $\circ 2 \mathrm{X}$ & Sexual & 29 & Brachiaria ruziziensis \\
\hline 5 & Parent $+2 \mathrm{X}$ & Sexual & 110 & Brachiaria ruziziensis \\
\hline 6 & Parent $q 2 \mathrm{X}$ & Sexual & 41 & Brachiaria ruziziensis \\
\hline 7 & Parent o $2 \mathrm{X}$ & Sexual & 100 & Brachiaria ruziziensis \\
\hline 8 & Parent o $2 \mathrm{X}$ & Sexual & $143 \mathrm{~A}$ & Brachiaria ruziziensis \\
\hline 9 & Progeny & Apomictic & $4118-6$ & $41 \times 18$ \\
\hline 10 & Progeny & Apomictic & $4118-10$ & $41 \times 18$ \\
\hline 11 & Progeny & Apomictic & $4118-12$ & $41 \times 18$ \\
\hline 12 & Progeny & Apomictic & 2918-14 & $29 \times 18$ \\
\hline 13 & Progeny & Apomictic & 2918-18 & $29 \times 18$ \\
\hline 14 & Progeny & Apomictic & 10018-1 & $100 \times 18$ \\
\hline 15 & Progeny & Apomictic & $10018-6$ & $100 \times 18$ \\
\hline 16 & Progeny & Apomictic & $10018-16$ & $100 \times 18$ \\
\hline 17 & Progeny & Apomictic & $143 A$ 18-3 & $143 \mathrm{~A} \times 18$ \\
\hline 18 & Progeny & Apomictic & $143 \mathrm{~A} 18-23$ & $143 \mathrm{~A} \times 18$ \\
\hline 19 & Progeny & Apomictic & $4171-9$ & $41 \times 71$ \\
\hline 20 & Progeny & Apomictic & $4171-20$ & $41 \times 71$ \\
\hline 21 & Progeny & Apomictic & $10071-4$ & $100 \times 71$ \\
\hline 22 & Progeny & Apomictic & $10071-8$ & $100 \times 71$ \\
\hline 23 & Progeny & Apomictic & 4194-19 & $41 \times 94$ \\
\hline 24 & Progeny & Apomictic & $4194-24$ & $41 \times 94$ \\
\hline 25 & Progeny & Apomictic & 143A 94-3 & $143 \mathrm{~A} \times 94$ \\
\hline 26 & Progeny & Apomictic & $143 \mathrm{~A} 94-4$ & $143 \mathrm{~A} \times 94$ \\
\hline 27 & Progeny & Apomictic & $143 \mathrm{~A} 94-11$ & $143 \mathrm{~A} \times 94$ \\
\hline 28 & Progeny & Apomictic & 11094-1 & $110 \times 94$ \\
\hline 29 & Progeny & Apomictic & 11094-7 & $110 \times 94$ \\
\hline 30 & Progeny & Apomictic & $11094-16$ & $110 \times 94$ \\
\hline
\end{tabular}

nium bromide (CTAB) method (Dellaporta et al. 1983, Zhang and Stewart 2000).

\section{Molecular evaluation}

DNA quantification was performed with spectrophotometry at $260 \mathrm{~nm}$ and its quality was estimated on $1 \%$ agarose gels with $1 \mathrm{X}$ TAE buffer (Sambrook et al. 1989).

\section{AFLP}

Digestion, adapter ligation, pre-amplification reactions and selective amplification were performed as indicated by GIBCO-BRL Life Technologies AFLPTM. For the selective amplification, the following primer combinations were evaluated: E$\mathrm{AAC}+\mathrm{M}-\mathrm{CAC}, \mathrm{E}-\mathrm{AAC}+\mathrm{M}-\mathrm{CTG}, \mathrm{E}-\mathrm{ACC}+\mathrm{M}-$ CAC, E-ACC + M-CTG, E-AGG + M-CTC, E-AGG + M-CTA, E-ACT + M-CTC y E-ACT + M-CTA and those which produced clear differences between parents and progeny were selected (Table 2). The fragments obtained in the selective amplification were separated on denaturing $6 \%$ polyacrylamide gels (19:1), 7.5 $\mathrm{M}$ urea and $1 \mathrm{X}$ TBE buffer in a BioRAD ${ }^{\circledR}$ vertical sequencing chamber and an EC Apparatus Corporation ${ }^{\circledR}$ model 3000PW power source. The reagents required for electrophoresis and staining were prepared according to Sambrook et al. (1989). Prior to running the polymerase chain reaction (PCR) products, the gel was pre-run for 30 min at $55{ }^{\circ} \mathrm{C}$. Subsequently, $10 \mu \mathrm{L}$ of the samples previously mixed and heated with a run buffer at $65{ }^{\circ} \mathrm{C}$ were loaded and kept cold until their run. Electrophoresis was run at 80 watts (1000 volts) for $3 \mathrm{~h}$; the gel was then stained in $0.2 \%$ silver nitrate solution for $30 \mathrm{~min}$ and developed with sodium carbonate solution, made with $30 \mathrm{~g}$ of sodium car- 


\begin{tabular}{|c|c|c|c|c|}
\hline No. & Primers & Total fragments & Polymorphic fragments & $\%$ polymorphism \\
\hline \multicolumn{5}{|c|}{ AFLP } \\
\hline 1 & $E A A C+M C A C$ & 54 & 47 & 87.04 \\
\hline 2 & $E A C C+M C A C$ & 43 & 40 & 93.02 \\
\hline 3 & $E A C T+M C T C$ & 29 & 28 & 96.55 \\
\hline \multirow[t]{2}{*}{4} & $E A C T+M C T A$ & 35 & 32 & 91.42 \\
\hline & Total & 161 & 147 & 91.30 \\
\hline \multicolumn{5}{|l|}{ CAPS } \\
\hline 1 & C-06 5'-GAA CGG ACT C-3' & 27 & 23 & 85.18 \\
\hline 2 & C-08 5'-TGG ACC GGT G-3' & 15 & 12 & 80.00 \\
\hline 3 & C-15 5'-GAC GGA TCA G-3' & 23 & 17 & 73.91 \\
\hline \multirow[t]{2}{*}{4} & C-19 5'-GTT GCC AGC C-3' & 19 & 15 & 78.95 \\
\hline & Total & 84 & 67 & 79.76 \\
\hline
\end{tabular}

bonate $\left(\mathrm{Na}_{2} \mathrm{CO}_{3}\right)$ per $\mathrm{L}$ of distilled water, which was maintained at $6{ }^{\circ} \mathrm{C}$; before use, $3 \mathrm{~mL}$ of $37 \%$ formaldehyde and $400 \mu \mathrm{L}$ of sodium thiosulfate (10 $\mathrm{mg} \mathrm{mL}^{-1}$ ) were added. When the first bands were developed, after approximately $4 \mathrm{~min}$, the solution was discarded and replaced with fresh solution to continue the development for another $15 \mathrm{~min}$. Finally, the gels were photodocumented for analysis.

\section{CAPS}

It was performed with a modification, which consisted in digesting the DNA with the Eco RI enzyme prior to $\mathrm{PCR}$, while in the original technique the amplified fragments are digested (Konieczny and Ausubel 1993). The modification provided reliable, informative and reproducible results between experiments, because the conformational change in the molecule used in PCR (fragments) exhibits a less complicated topography. PCR amplifications were performed on an Applied Biosystems ${ }^{\circledR}$ 9700 thermocycler according to the methodology of Williams et al. (1990). The selected RAPD primers were $\mathrm{C}-06, \mathrm{C}-08, \mathrm{C}-15$ and $\mathrm{C}-19$, of 25 primers previously evaluated by the ROTH Company, Germany (Table 2). The thermocycling consisted of one minute at $94{ }^{\circ} \mathrm{C}$ for pre-denaturation, 38 cycles [94 ${ }^{\circ} \mathrm{C}, 20 \mathrm{~s} ; 40{ }^{\circ} \mathrm{C}, 15 \mathrm{sec} ; 72{ }^{\circ} \mathrm{C}, 60 \mathrm{~s}$ ] and a 5 -min final extension cycle at $72{ }^{\circ} \mathrm{C}$. The products were separated in acrylamide (29: 1) double-layer gels where the run-off gel was prepared at $16 \%$. The run buffer was $1 \mathrm{X}$ Tris-Glycine and it was run for $4 \mathrm{~h}$ with $40 \mathrm{~V} / \mathrm{cm}$ in a C.B.S. Scientific $C O{ }^{\circledR}$ model MVG-216-33 vertical chamber, with an EC Apparatus Corporation ${ }^{\circledR}$ model EC-105 power source. The gels were stained with $0.2 \%$ silver nitrate $\left(\mathrm{AgNO}_{3}\right)$, visualized and documented with a white light transilluminator (Sambrook et al. 1989).

\section{Statistical analysis}

A binary matrix was constructed with the products amplified in each technique. Genetic similarities were calculated with $\mathrm{Nei}$ and Li/Dice distance (Nei and Li 1979) and the method for clustering was the Unweighted Pair Group Method with Arithmetic mean (UPGMA) with a 500-replicate bootstrap analysis. The program used was FreeTree $\vee$ 0.9.1.50 and the trees were drawn with the TreeView program (Win32) 1.6.6. A simple correspondence factor analysis was also carried out with the molecular data obtained with both techniques, to determine the percent contribution of the markers to the differentiation of the genotypes with respect to apomictic or sexual character.

\section{RESULTS AND DISCUSSION}

The number of markers obtained was acceptable and informative; 147 corresponded to AFLP, of which $91.3 \%$ were polymorphic, while 87 were obtained with CAPS with $79.7 \%$ polymorphism. Both types of markers differentiated each of the genotypes studied (Table 2). In the consen- 
Poblete-Vargas et al. Ecosistemas Molecular differentiation of Brachiaria sp.

Ecosist. Recur. Agropec. 5(13):71-80,2018

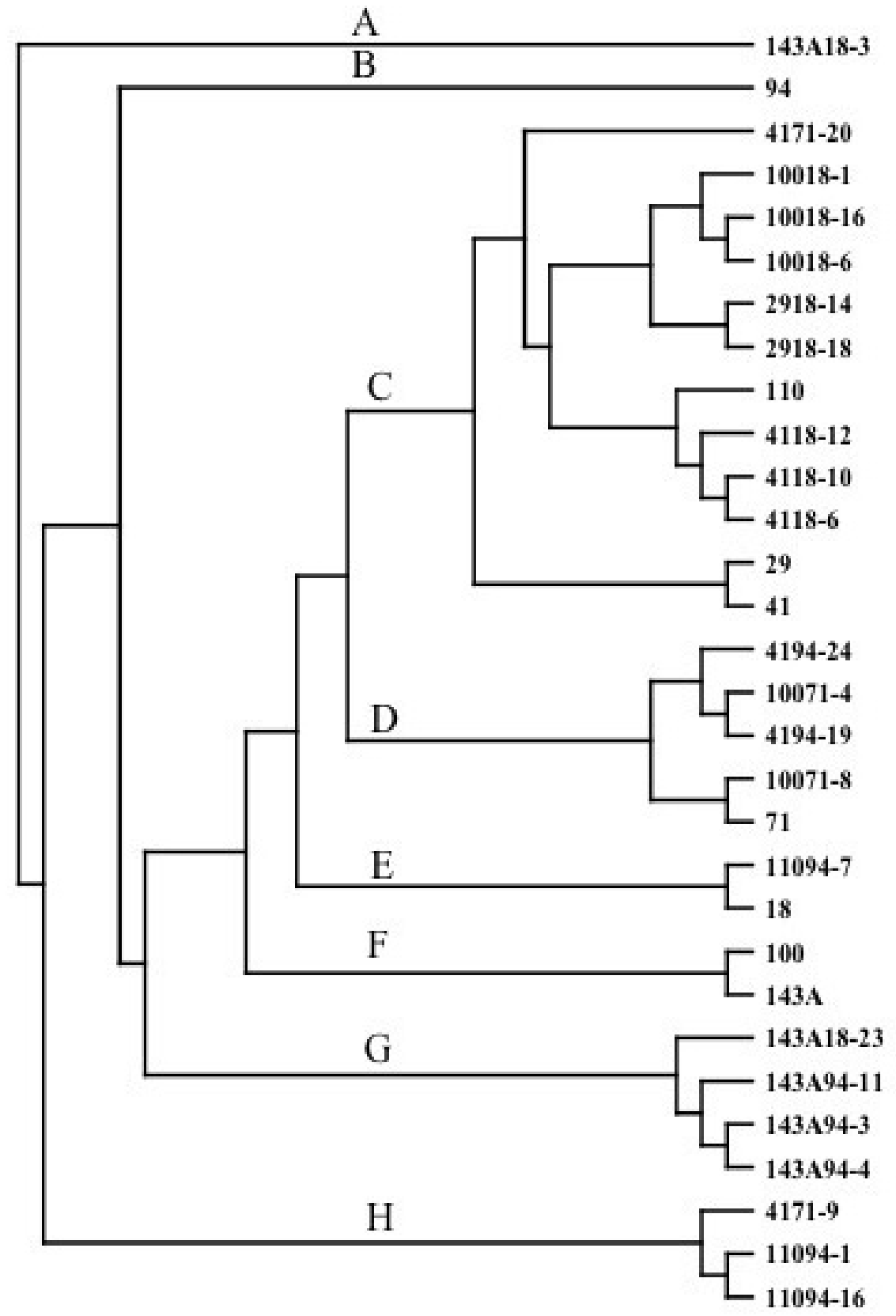

Figure 1. Consensus phenogram of apomictic and sexual genotypes of Brachiaria spp., constructed with Amplified Fragments Length Polymorphism (AFLP) genetic markers. Unweighted Pair Group Method with Arithmetic Mean (UPGMA) clustering and random sampling with 500 replicates (bootstrapping).

sus phenogram, constructed with the AFLP markers (Figure 1), three main groups are distinguished: group A comprised by the hybrid 143A-18-3; group $B$ defined by the $0^{7} 94$ and distant from the other two males; and group $\mathrm{H}$ with genotypes 4171-9, 11094-1 and 11094-16. Group B was related to the rest of the genotypes, which were clustered based on close genetic similarities. Groups $C$ and $G$ show 


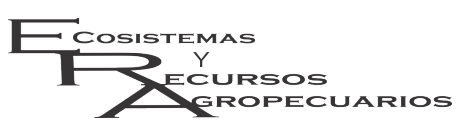

groupings of full siblings. The $\mathrm{C}$ group concentrates genotypes with greater influence of $O^{7} 18$ [10018-1, 10018-16 and 10018-6] and [4118-12, 4118-10 and 4118-6], which is a dominant apomict, and $q 110$, 29 and 41; this group also includes the genotype 4171-20, which must share characters with the parent $q 41$ and the indicated half-siblings. Group $G$ contains full siblings originating from $o$ 143A and $\sigma^{7} 94$ [143A94-11, 143A94-3 and 143A94-4, in addition to genotype 143A18-23, which apparently shares more information with parent o 143A than with $0^{7} 18$. On the other hand, the genotype $143 \mathrm{~A} 18-3$ is found as an independent group (group A) when it was expected to be grouped with its genetic similarities. The discrepancy in this behavior may be due to mutations in the genome that generate polymorphisms in the profiles obtained. These alterations are common in plants of asexual/vegetative reproduction and it is relatively easy to detect them with molecular markers. Group D contains $\sigma^{7} 71$ and some of its progeny, group $E$ has $\sigma^{7} 18$, and finally group $F$ contains o 100 and 143A. The fact that all the females were distributed throughout the phenogram suggests the genetic contribution of $B$. ruziziensis used as a female parent. The AFLP markers were able to differentiate all the genotypes and to show the close genomic relationship between some of them; however, they were insufficient to mark the locus or loci responsible for the apomixis (Hand and Koltunow 2014).

Figure 2 shows the grouping formed with CAPS data; $\sigma^{x} 18$ remained independent of the two main groupings, group I and group II, suggesting less genetic similarity according to these markers. Group I includes the parent $\sigma^{7} 94$, the genotypes with greater genetic influence of this parent, as well as some genotypes related to the parents $\sigma^{7}$ 18 and $\sigma^{7} 71$. Group II comprises the females 29, 110 and 41 , as well as the hybrids that shared more characters with them, but also $0^{7} 71$, probably due to its facultative character. The other two females, 100 and 143A, were grouped independently. As in the phenogram with AFLP data, the groupings with CAPS were also made up of subgroups of full siblings; for example, group I included 4: [10018-16,
Poblete-Vargas et al. Molecular differentiation of Brachiaria $s p$.

Ecosist. Recur. Agropec. 5(13):71-80,2018

10018-6]; [143A94-3, 143A94-4]; [11094-16, 11094$1,11094-7]$ and [2918-18, 2818-14], while group II comprised 2 subgroups, [4118-10 and 4118-12] and [4194-19, 4194-24], mainly. There are several matches between the two phenograms; there were groupings of full siblings, as well as females 100 and $143 \mathrm{~A}$ or 29 and 41 , which stayed together but in separate groups, which explains their close genetic resemblance. On the other hand, in both phenograms it was possible to separate the females from the males; however, in the case of CAPS, $0^{7}$ 71 was not separated from the group of females 29, 110 and 41, perhaps due to their particular qualities. The distribution behavior observed in both phenograms can be useful, especially when considering the alternative of selecting any of the females used in the present study due to their degree of genetic similarity, or $0^{x} 18$ and 94 that showed less relatedness between them in both marker systems. Another observation was that the progeny was mainly influenced by the genetic characters of the parents $\sigma^{7} 18$ and $\sigma^{7} 94$, and to a lesser degree by $0^{7} 71$.

The search for characters associated with apomixis or sexuality with techniques that detect anonymous markers such as those used in this study has proved difficult, unless sufficient molecular data are considered; this probability increases if precise information is available for the two loci that are assumed to control apomixis in plants (Noyes and Rieseberg 2000). DNA markers associated with apomixis (AFLPs and SCARs) have been reported for the genera Paspalum (Labombarda et al. 2002), Pennisetum (Ozias-Akins et al. 1998), Hieriacium (Catanach et al. 2006) and Trichloris crinite (Cavagnaro et al. 2006). In this study, the CAPS markers detected a DNA fragment called C15-8 that differentiated the sexual parents (o) from the apomictic ones $\left(\sigma^{7}\right)$ and that could be associated with the sexuality of $B$. ruziziensis; this may indicate the absence of this distinctive character in the apomictic genotypes used as males. This fragment was inherited from hybrids such as 9, 10, 12, 14, 15, 16, 18, 19, 22, 26 and 27 (Figure 3) that were selected at the field level as apomicts, 
Poblete-Vargas et al. Ecosistemas Molecular differentiation of Brachiaria sp.

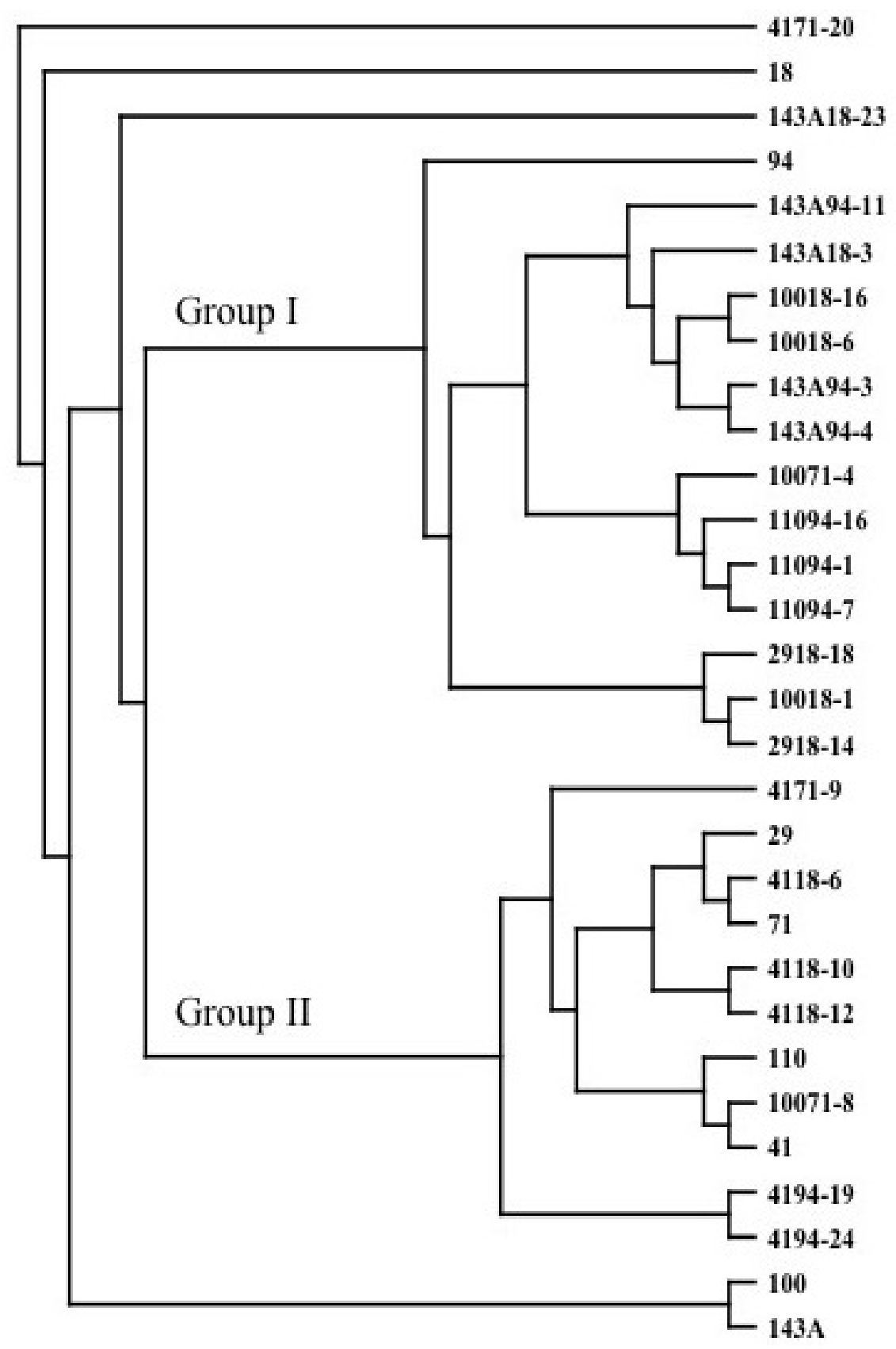

Figure 2. Consensus phenogram of apomictic and sexual genotypes of Brachiaria spp., constructed with Cleaved Amplified Polymorphic Sequences (CAPS) genetic markers, Unweighted Pair Group Method with Arithmetic Mean (UPGMA) clustering and random sampling with 500 replicates (bootstrapping).

which may indicate that the $B$. ruziziensis line used as female is not the same as that of the tetraploid males. This observation can also be supported by separating the females in the two phenograms ob- tained. An alternative way of determining the effect of this marker is to observe the behavior at field level with respect to sexuality in different environments, to confirm it in a traditional way. The informa- 


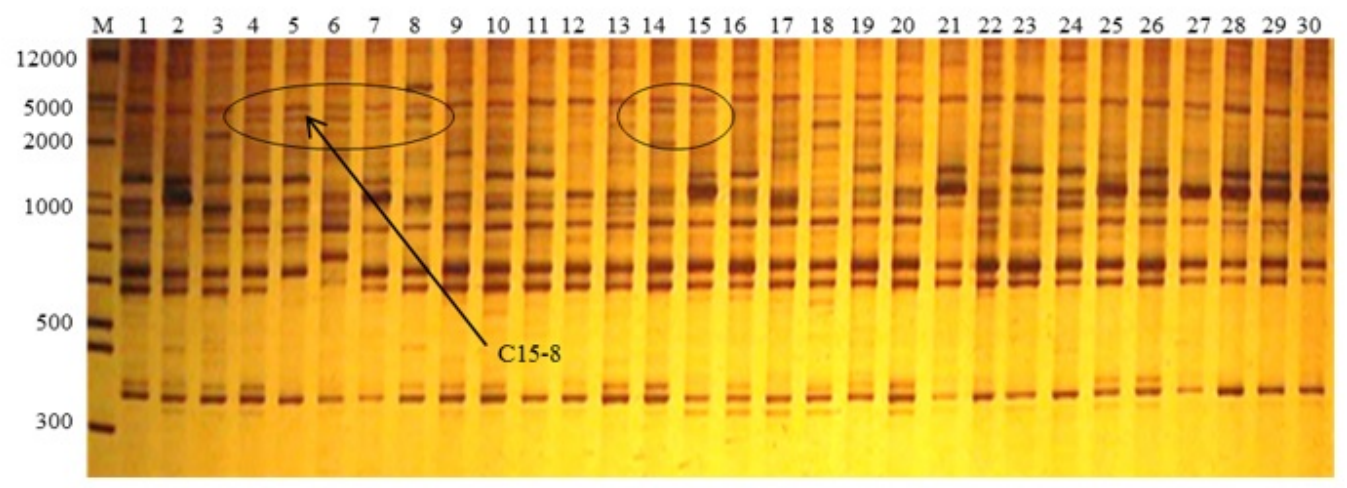

Figure 3. Cleaved Amplified Polymorphic Sequences (CAPS) profiles of 30 genotypes of Brachiaria spp., obtained with the ROTH C-15 primer. Lanes 1-3 correspond to $4 \mathrm{X}$ males, 4-8 to $2 \mathrm{X}$ females and 9-30 to hybrids. The ellipses indicate a distinctive DNA fragment in the females (lanes 4-8) that were inherited by some hybrids and named C15-8. Lane M indicates the molecular weight marker $\phi$ X174 DNA / Haelll.

Table 3. Eigenvalues of genotypes of the genus Brachiaria, product of simple correspondence factor analysis.

\begin{tabular}{cccc}
\hline Principal Component & Eigenvalue & Explained variance in (\%) & Cumulative variance in (\%) \\
\hline AFLP & & & \\
1 & 0.074 & 13.55 & 13.55 \\
2 & 0.0627 & 11.47 & 25.02 \\
3 & 0.0602 & 11.02 & 36.03 \\
4 & 0.0396 & 7.25 & 43.29 \\
5 & 0.0382 & 7.00 & 50.28 \\
6 & 0.0338 & 6.18 & 56.47 \\
CAPS & & & \\
1 & 0.0654 & 12.86 & 12.86 \\
2 & 0.0628 & 12.36 & 25.22 \\
3 & 0.0441 & 8.67 & 33.89 \\
4 & 0.0366 & 7.2 & 41.08 \\
5 & 0.0346 & 6.81 & 47.9 \\
6 & 0.0324 & 6.37 & 54.27 \\
\hline
\end{tabular}

tive capacity of this CAPS technique has also been shown by authors such as Möhring et al. (2005) who detected self-incompatibility characters in Brassica species. The relative ease of differentiating sexual genotypes (Brachiaria ruziziensis) from interspecific apomicts ( $B$. brizantha and $B$. ruziziensis) in the present study could be favored by the genomic contrast of the species types involved in the crosses.

The simple correspondence factor analyses (Table 3) performed for the AFLP and CAPS data allowed weighting the value contributed by each component (amplicon) (Dore and Ojasso 2001). With both techniques, the first six principal components explain $56.47 \%$ for AFLP and $54.27 \%$ for CAPS, which suggests the effectiveness of the markers used to differentiate each of the genomes. The AFLP and CAPS techniques were appropriate to estimate the genetic relationship of parents and hybrids of the genus Brachiaria. The genetic contribution of male parents 18 and 94 was shown in the progeny, compared to that provided by parent $0^{7} 71$. The CAPS technique was able to clearly differentiate the diploid genotypes of $B$. ruziziensis (female) from the tetraploid genotypes of $B$. brizantha $X$ B. ruziziensis used as males. The CAPS factorial analysis allowed correlating the DNA fragment called C15-8 as a distinctive character of the female sexual parents, unlike that of the male apomictic parents. 


\section{LITERATURE CITED}

Azofeita-Delgado A (2006) Uso de marcadores moleculares en plantas; aplicación en frutales del trópico. Agronomía Mesoamericana 17: 221-242.

Bicknell RA, Koltunow AM (2004) Understanding apomixis: recent advances and remaining conundrums. The Plant Cell 16: S228-S245.

Catanach AS, Erasmuson SK, Podivinsky E, Jordan BR, Bicknell R (2006) Deletion mapping of genetic regions associated with apomixis in Hieracium. Proceedings of the National Academy of Sciences of the United States of America 103: 18650-18655.

Cavagnaro PF, Cavagnaro JB, Lemes JL, Masuell RW, Passera CB (2006) Genetic diversity among varieties of the native forage grass Trichloris crinite based on AFLP markers, morphological characters, and quantitative agronomic traits. Genome 49: 906-918.

CIAT (2002) Annual Report: Part 1: Grass and legume genotypes with high forage attributes. CIAT. Cali, Colombia. 23p.

De la Cruz-Llanas JJ, Vera-Graziano J, López-Collado J, Pinto MV, Garza-García R (2005) Una técnica simple para el desarrollo de ninfas de Aeneolamia postica (Homoptera: Cercopidae). Folia Entomológica Mexicana 44: 91-93.

Dellaporta SL, Wood J, Hicks JB (1983) A plant DNA minipreparathion: Version II. Plant Molecular Biology Reporter 1: 19-21.

Do Valle CB, Miles JW (2001) Breeding of apomictic species. In: CYMMYT (Ed.). The flowering of apomixis: from mechanisms to genetic engineering. CYMMYT/IRD. Mexico. pp: 137-152.

Dore JC, Ojasoo T (2001) How to analyze publication time trends by correspondence factor analysis: Analysis of publications by 48 countries in 18 disciplines over 12 years. Journal of the Association for Information Science and Technology 52: 763-769.

FAO (2009) El estado mundial de la agricultura y la alimentación. Organización de las Naciones Unidas para la Agricultura y la Alimentación. Roma, Italia. 184p.

Grimanelli D, Leblanc O, Perotti E, Grossniklaus U (2001) Developmental genetics of gametophytic apomixis. Trends in Genetics 17: 597-604.

Hand ML, Koltunow AM (2014) The genetic control of apomixis: Asexual seed formation. Genetics 197: 441-450.

Koltunow AM, Bicknell RA, Chaudhury AM (1995) Apomixis: Molecular strategies for the generation of genetically identical seeds without fertilization. Plant Physiology 108: 1345-1352.

Konieczny A, Ausubel FM (1993) A procedure for mapping Arabidopsis mutations using co-dominant ecotypespecific PCR-based markers. The Plant Journal 4: 403-410.

Labombarda P, Busti A, Caceres MA, Pupilli F, Arcioni S (2002) An AFLP marker tightly linked to apomixis reveals hemizygosity in a portion of the apomixis-controlling locus in Paspalum simplex. Genome 45: 513-519.

Lascano CE (2002) Caracterización de las pasturas para maximizar producción animal. Archivos Latinoamericanos de Producción Animal 10: 126-132. 
Miles JW, Do Valle CB, Rao IM, Euclides VP (2004) Brachiaria grasses. In: Sollenberger LE, Moser LE, Burson BL (eds) Warm-season $\left(C_{4}\right)$ grasses. Agronomy monograph 45, American Society of Agronomy, Crop Science Society of America, Soil Science Society of America. Madison, WI, USA. pp: 745-783.

Möhring S, Horstmann V, Esch E (2005) Development of a molecular CAPS marker for the self-incompatibility locus in Brassica napus and identification of different $S$ alleles. Plant Breeding 124: 105-110.

Nei M, Li WH (1979) Mathematical model for studying genetic variation in terms of restriction endonucleases. Proceedings of the National Academy of Sciences United States of America 76: 5269-5273.

Noyes RD, Rieseberg LH (2000) Two independent loci control agamospermy (apomixis) in the triploid flowering plant Erigeron annuus. Genetics 155: 379-390.

Ozias-Akins P, Roche D, Hanna WW (1998) Tight clustering and hemizygosity of apomixis-linked molecular markers in Pennisetum squamulatum implies genetic control of apospory by a divergent locus that may have no allelic form in sexual genotypes. Proceedings of the National Academy of Sciences of the United States of America 95: 5127-5132.

Rao IM, Miles JW, García R, Ricaurte J (2006) Selección de híbridos de Brachiaria con resistencia a aluminio. Pasturas Tropicales 28: 12-15.

Risso-Pascotto C, Pagliarini MS, Valle CB (2005) Meiotic behavior in interspecific hybrids between Brachiaria ruziziensis and Brachiaria brizantha (Poaceae). Euphytica 145: 155-159.

Sambrook J, Fritsch EF, Maniatis T (1989) Molecular cloning: a laboratory manual. $2^{a}$. ed. Cold Spring Harbor Laboratory Press, NY, USA. pp: 18.51-18.57.

Savidan Y (2000) Apomixis: Genetics and breeding. In: Janick J (Ed.). Plant Breeding Reviews Volume 18. Wiley. New York, USA. pp: 13-86.

Williams JGK, Kubelik AR, Livak KJ, Rafalski JA, Tingey SV (1990) DNA polymorphisms amplified by arbitrary primers are useful as genetic markers. Nucleic Acids Research 18: 6531-6535.

Zhang J, Stewart JMD (2000) Economical and rapid method for extracting cotton genomic DNA. The Journal of Cotton Science 4: 193-201.

Zorzatto C, Chiari L, Araújo-Bitencourt G, Do Valle CB, De Campos-Leguizamón GO, Schuster I, et al. (2010) Identification of a molecular marker linked to apomixis in Brachiaria humidicola (Poaceae). Plant Breeding 129: 734-736. 